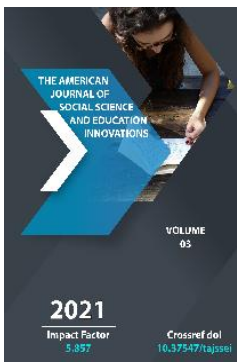

\title{
Learning In Business English
}

Rakhimov Adham Barat Oglu

Jizzax Polytechnic Institute Assistant, Jizzakh City, Uzbekistan

Journal Website:

http://usajournalshub.c

om/index,php/tajssei

Copyright: Original content from this work may be used under the terms of the creative commons attributes 4.0 licence.

\section{ABSTRACT}

The article considers the peculiarities of teaching Business English. The author distinguishes two groups of students and suggests approaches and tips for facilitating learning Business English for students with poor linguistic background.

\section{KEYWORDS}

Business English, teaching, linguistic skills, business skills, communicative skills, peculiarities of teaching at different levels of proficiency in English.

\section{INTRODUCTION}

In the modern society in times when, despite the global turbulence, the economic ties between countries are getting wider, the importance of learning foreign languages, especially for those who are in business or study to make a business career, is definite and apparent. The main aim of the current higher education is to provide modern business 
students with the very knowledge that enable to develop their potential and to make balanced and suitable decisions for getting better working prospects in their future career life. For professional and career advancement future specialists need conditions under which they could form their individual willingness to work on mastering knowledge and ways of working in the professional sphere. These conditions will allow students to immerse themselves in a real professional activity. The discipline "Foreign Language" has been transformed into the means of achieving personal professional development.

The significance of LSP (language for specific purposes) lies in its interdisciplinary character, and it is combined with the main disciplines to acquire the necessary expertise and form professional qualities of the person. Moreover, foreign languages contribute to the professional competence of students. Professional language is characterised by a limited sphere of specific communication. Professional language has peculiar grammar, but its most distinctive feature is the lexical and phraseological structure. Professional language is a narrower concept than a general literary language as its functions are gnoseological, cognitive, epistemic, informative, logical, intellectual and communicative.

Business English is not some separate entry from general English. The language skills for business English are the same as for general English; it is simply that the contexts for using the language are different. When teaching business English it is important to distinguish between students who are already in work and A business English course can include all the language elements such as listening speaking, pronunciation and grammar, together with various business skills. These refer to what students actually do in their work, and include:

- Reading (e.g. business pages of newspapers; reports; contracts; manuals);

- Writing (letters, emails, reports, contracts);

- Presentations;

- Telephoning;

- Meetings and discussions;

- Negotiations;

- Interviews (e.g. job, appraisal).

\section{MATERIALS AND METHODS}

It is unlikely that pre-experience students are familiar with these skills even in their own language, so it is necessary to devote time to expose them to the skills and sub-skills involved, not just the language associated with them. Students in work are normally experienced in the various business skills, although they are not necessarily good at them in their own language. The teacher should have a good basic understanding of the business skills, otherwise it will be difficult to teach students with confidence.

If the teacher needs to improve understanding business skills there are plenty of materials that cover all these topics as well as many other useful business concepts such as teambuilding, project management and leadership.

A business skill refers to what the student actually uses language for in the work place. A business concept is the idea that the businessrelated words describe; for example, a service economy, human recourses.

It is unlikely that pre-experience students will be familiar with all, or even many, of the 
business concepts that are implicit in English, so the teacher may need to spend a significant amount of time teaching the concepts as well as the language.

\section{RESULT AND DISCUSSION}

Business vocabulary is an integral part of business English. For some pre-experience students, business vocabulary represents what they learn on a business English course. Students in jobs or executive students, that is, students who already have job experience, however, normally know the specific language needed for their work interests: even elementary students who do not have the grammar to string sentences together may know the words for their job-related vocabulary in English.

There are now many more books for specialist vocabulary areas, covering subjects such as economics, banking and finance, tourism, mass media, computing, telecommunications, and Human Resource Management.

The Internet can be used to research topic areas, which do not have EFL books dedicated to them, such as information service.

Part of the role of the business English is to teach effective communication. Communicating effectively includes:
- Speaking clearly, at an appropriate speed and volume;

- Clarifying and summarizing frequently;

- Listening carefully;

- Structuring your arguments (OK, that's all for my first point. My second point is....);

- Using clear, short, simple sentences to convey meaning ( KISS principle);

- Preparing difficult points in advance;

- Providing feedback to the speaker to show you are listening (e.g. I see, That's interesting).

On the whole, one needs to be able to express oneself concisely to impress the audience, one also needs to be a good listener and good at asking questions. Communication is really more of a package than an individual skill.

The KISS principal means Keep It Short and Simple. It is a very handy acronym to convey to our students the idea that they need to avoid over-long, complicated sentences.

However, students can be confused when the teacher reformulates something they say and the end result is longer than their original utterance. If this occurs< you need to explain that the KISS principal is an oversimplification, and is just a way of putting complex linguistic notions into an accessible form for the student, as shown in the example below.

\begin{tabular}{|c|c|}
\hline Original version & Reformulated version \\
\hline $\begin{array}{c}\text { I will use this approved discussed data in my } \\
\text { secondary analysis. }\end{array}$ & $\begin{array}{c}\text { I would like to discuss this data with you later. I } \\
\text { will use it in my secondary analysis. }\end{array}$ \\
\hline
\end{tabular}


Some tips for teaching business skills include:

- Minimal input (keep input to a minimum);

- Learning by doing (i.e. give the student the opportunity to learn through doing, for example, role play activities in the output stage of the lesson. This allows the teacher to find out student's strength and weaknesses;

- Feedback ( look at the communicative performance first and the linguistic performance second.);

- Work diagnostically (use the Test-Teach method, i.e. get students to perform a task, evaluate their performance instead of presenting the language first and then get the students to practice it.).

Student's learning background leaves much to be desired. In the process of learning a foreign language, students got just a glimpse of its system and acquired the ability to use language material to produce correct language forms and structures, if anything. As a result of such training the main practical goal of mastering foreign language, that is, to be able to adequately express their own thoughts and ideas to understand the interlocutor in a reallife situation, was not achieved.

For learning business English, students need language skills:

- Grammar knowledge, grammatical structures;

- Phonological elements knowledge, syllable stress, sentence stress, weak forms, intonation, articulation, a system of phonetic transcription;

- Vocabulary, i.e. the words, that are typically used when talking about a particular subject;

- Listening for gist, listening for detail; listening strategies;
- Ability to speak concisely, fluency versus accuracy.

Grammar will be dealt with diagnostically. If a student needs any remedial work, the teacher will do a short input in class and then give the student suitable exercises for homework. Remedial grammar helps the student to improve grammatical knowledge according to the needs rather than according to a prescribed syllabus (i.e. list of main subjects in a course of study). Finding out the student's areas of grammatical weakness and then helping the student to improve these, rather teaching grammatical items with which the student does not necessarily have difficulties.

Pronunciation requires special efforts. If a student's speech or reading is difficult to understand, the student can practice making the correct movements with lips and tongue. Reading aloud is very useful. However, some students are not willing to listen to each other. Take a short text; let the student read it first. Then together prepare text for reading aloud by "marking up" necessary features: making individual sounds, articulation, syllable stress, sentence stress, rhythm.

Rhythm implies the sequence of strong and weak elements in language. Weak forms in speech are "little" words which are usually not stressed in spoken English.

So called "little" words include functional words such as prepositions, modals, and pronouns, which have little meaning of their own but which contribute to the grammatical construction. Syllable stress means stress on a particular syllable in a word (as opposed to "sentence stress); SER-vice. Sentence stress which falls in a sentence is more important 
than the stress of the individual words in a sentence. Encourage students to do as much listening as possible outside the classroom.

In class the teacher or students correct mispronunciations throughout the class.

Students learn a great deal of vocabulary "incidentally". It is important for both student and teacher to make a note of the new word or phrase, and the context in which it is used, in order to recycle it later, so it can be used again.

Set aside time to look at different vocabulary storage techniques with your students such as flash cards, vocabulary books, (small ones which the student can put in pocket of handbag are best and storing the vocabulary in computer. Make sure that the student notes down all new words, ideally in "model" sentences related to their shares of interests to remember words more easily. At the same time, the student can also make a note of the word's syllable stress, collocations, grammatical structure, opposites, synonyms and so on.

Thus any vocabulary program needs two strands: an explicit strand to present the teachable word knowledge aspects of high value words and an incidental learning strand where those words are consolidated and more is learned about ones, as a multitude of other new words are met. To facilitate incidental learning is to maximize learners' exposure to English. This can be done orally in a number of ways: maximizing the amount of English used in the classroom; using group work, where learners can learn new words from each other during their interactive discussions (not all members of a group will know the same words); encouraging communication with proficient English users whenever possible.

Specific activities targeted at vocabulary expansion include: reading texts (authentic materials such as newspapers articles); vocabulary books; using listening inputs for vocabulary building (listening news is an excellent way of broadening the student's vocabulary. However, the lack of vocabulary will hinder the student's ability to listen. Encourage the student to write down the sentences in which the word or words occurred.

Listening is often thought of as a passive skill as opposed to the "active" skill of speaking. In fact, listening is active, dynamic process; the brain needs to decode incoming signals. Students sometimes rely too on their knowledge of the linguistic system to make sense of what is saying ('bottom-up processing). However, they also need "topdown processing" this relies on non-linguistic knowledge to decode the speaker's message. The listening tasks are designed to give the student maximum help in understanding the situation before listening. The student then listens to try and catch the general meaning (extensive listening); this may be followed by detailed listening tasks (intensive listening). Expand the student's language by focusing on the on the linguistic features of the input (e.g. vocabulary, sentence construction; phonology, cultural elements).

Speaking can be more difficult than listening. The teacher should provide useful vocabulary before the speaking. Diagnostic vocabulary and grammatical work will be based on the speaking feedback. Fluency is not one skill, but a range of skills. It encompasses: - syntax and 
grammar; - pronunciation; - stress, rhythm and intonation; - vocabulary; - quality of ideas; confidence; - listening skills.

It is very difficult for students to exert control over all these elements when verbalizing ideas. The teacher gives prompts. It is important to tell the students that you are as interested in their ideas as in the language used. This should encourage the student to use these ideas and to stretch linguistic capabilities.

\section{CONCLUSION}

Teaching and learning business English require a great deal of time and effort. It is essential to tailor teaching techniques to the context and interests of student's future profession from the first course. With the right teaching techniques and approach the teacher can give students the tools with which to continue the learning process independently at the end of the course.

\section{REFERENCES}

1. Celce-Murcia, M., Olshtain, E. Discourse and Context in Language Teaching. Cambridge: Cambridge University Press, 2014. - P. 30-180.
2. Donna, S. Teach Business English. Cambridge: Cambridge University Press, 2011. - P. 126-331.

3. Richards, J.C., Rodgers, T.S. Approaches and Methods in English Teaching. Cambridge: Cambridge University Press, 2014. - P. 83-150.

4. Harding, K. English for Specific Purposes. Oxford: Oxford University Press, 2007. P.50- 174 .

5. Laufer, B., Hulstijn, J. Incidental Vocabulary Acquisition in a Second Language: the Construct of Task-Induced Involvement // Applied Linguistics. - 2001- № 22. - P. 18 25.

6. Schmitt, N. Current Perspectives on Vocabulary Teaching and Learning. - UK, The University of Nottingham. - P. 745757.

7. Underhil, A. Sound Foundations: Learning and Teaching Pronunciation, Oxford: Macmillan Publishers Limited - 2007. - P. 51-74. 